\title{
Reflections on the Current Afghan Cultural Landscape
}

The following chapter is based on the endnote address of the conference, which was in essence an off-the-cuff illustrated response to certain issues raised by the speakers, panelists, and audience members during the presentations. It addresses eight key points that were felt to be of particular relevance.

\section{AFGHAN CULTURE IS DYNAMIC AND RESILIENT}

Afghan culture continues to be vibrant; there have in recent years been major achievements in the fields of archaeology (see Timuri, this volume; Paiman, this volume) and the management of collections (see Fisher, this volume), building conservation (see Abassi et al., this volume), fine arts, theatre, and film-making, while the media landscape has been transformed.

Despite this progress, a 'narrative of loss' seems to prevail, with culture portrayed as somehow beleaguered and under constant threat. While there are indeed challenges to face, the tendency to rake over dark tales of past looting and destruction does not reflect the wider picture of Afghan culture that, as history shows, is highly resilient.

There is a continued need for vigilance to ensure that the space for cultural expression is maintained, but also for a longer perspective that acknowledges the energy that exists among Afghans, especially the young. It is this energy that should set the cultural agenda for the future.

\section{A MYRIAD OF AFGHAN CULTURAL IDENTITIES EXIST}

A sense of cultural identity is, for the majority of Afghans, formed within their communities, where everyday practices might be as significant to their lives as 'high culture.' Formal cultural institutions have an important role to play in some respects, but are marginal to the majority of Afghans who quietly engage in cultural activities among their kin or community. ${ }^{1}$

The sheer diversity of the communities that make up the Afghan nation is reflected in the many faces of Afghan culture, which are constantly shifting (see Fontani \& Cassar, this volume, p. 2). Attempts to pin this down to one 'Afghan national culture' are of limited use, and can all too easily become politicized. Initiatives aimed at supporting culture should reflect the fact that it belongs to all Afghans - and not only the state.

\section{CULTURE CAN HELP TO UNITE-BUT CAN ALSO PROVOKE}

In recent years, culture has routinely — and often lazily — been portrayed as a way of uniting Afghans who might otherwise be in discord. There is no doubt that culture

\footnotetext{
${ }^{1}$ For a discussion of traditional Afghan cultural activities see N. Dupree, "Afghan Cultural Heritage Glimpsed Briefly," this volume.
} 
does have the potential to bring people together and build confidence in certain circumstances, but this is not something that will simply happen because people may share some notion of 'cultural identity.'

The country's recent history illustrates all too vividly how such an identity can be bitterly contested. One Afghan's poem might be another's heresy; an object perceived as beautiful by someone might be viewed as an idol by another (cf. Shaikhzada, this volume, p. 3); 'freedom of expression' is regarded with real ambivalence by many Afghans. In such circumstances, culture is anything but 'neutral.'

To remain relevant, culture needs in many ways to be provocative. A key challenge in Afghanistan today, however, is to understand and try to manage the tensions that certain forms of expression might elicit. Finding the balance between engendering curiosity, provoking debate, and giving offence may not be easy, but this should not become an excuse not to push boundaries.

\section{AFGHAN CULTURE IS THE RESPONSIBILITY OF AFGHANS}

The 'narrative of loss' described earlier has been accompanied by a parallel process of revisionism that (at times conveniently) implies that Afghans have no control over the state of their cultural heritage. This is particularly evident in the realm of illegal excavation and the looting of historic artifacts, which are routinely portrayed by officials as the work of 'foreign hands.' While the trafficking of objects certainly needs the complicity of outsiders to generate a profit, it is largely Afghans themselves who are looting archaeological sites today-just as it was Afghans who looted the National Museum in Kabul in 1993 (see Massoudi, this volume).

Likewise, the threats facing Afghanistan's built heritage are frequently portrayed as somehow beyond the control of the authorities. While the legal instruments to protect historic monuments are weak and the relevant institutions arguably lack capacity and experience, a great deal more can and should be done by those responsible for safeguarding such property. It is tragic that over the past decade, when government institutions have benefited from unprecedented levels of external support, they have failed to intervene to safeguard unique urban heritage from ill-conceived 'development' at the hands of Afghan property speculators.

\section{THE SEED OF A FLOURISHING CULTURE IS EDUCATION}

Several of the presentations during the conference have illustrated how ongoing projects aim to develop the skills of young musicians and craftspeople, for example (see Sarmast, this volume; W. Khalili, this volume). In addition to these commendable efforts, however, we need to do much more to integrate education into everything that we do (see Nazari et al., this volume, pp. 7-8 esp.).

This implies integrating culture into all aspects of the education system and beyond. Over-worked Afghan teachers clearly have many other priorities, and it is our responsibility to find imaginative ways of engaging young people and fostering their interest in their culture. This should extend beyond the classroom, with innovative material being developed for broadcast media, the internet, or though other means to engender curiosity and enhance understanding. 


\section{CULTURE CANNOT BE A 'QUICK-FIX'}

Cultural development is a process that requires a long-term perspective if it is to be effective. In many ways, this is incompatible with the project-based approach followed in recent years by most external donors, who expect tangible outcomes within a given period (see Nazari et al., this volume, pp. 9-11). Working within these constraints, it is important to be realistic about what can actually be achieved through 'projects' and identify ways that these might be the seeds of much longer-term processes that will gain their own momentum after initial support by donors. In some cases, it might be that investments are required to 'nudge' a process along, rather than achieving immediate results. The number of projects that seem to have disappeared over the past decade without trace amply illustrates just how fragile the 'quick-fix' approach can be.

\section{VALUE FOR MONEY}

In a context of massive aid flowing to Afghanistan over the past decade, culture is often portrayed as 'under-funded.' In fact, there has been a significant level of investment in various initiatives - the problem has arguably been how these funds have been spent. As the level of external resources for cultural development, as in other sectors, is diminishing, we all need to operate more cost-effectively if we are to keep up the momentum that has been established (cf. Nazari et al., this volume). This will require sacrifices; it is worth remembering that the Afghans and expatriates who dealt with the immediate aftermath of the destruction of the National Museum in Kabul in 1993/4 worked on a voluntary basis, and in some cases used their personal resources to fund rescue activities.

\section{CULTURE IS A COLLABORATIVE EFFORT}

Since the signature in 1922 of an agreement with French archaeologists, Afghans and foreigners have worked collaboratively on cultural initiatives in an atmosphere of mutual trust (see Bendezu et al., this volume). Despite the political upheavals since, this spirit has largely held and specialists have worked successfully together in a number of fields. In recent years, lack of effective coordination in the sector-for which UNESCO is formally mandated to assist the Afghan government - has affected the synergies that should prevail and, at times, resulted in a tendency towards rivalry and back-biting. All of us who are engaged in the sector perhaps need to examine our consciences to be sure that we are best serving the cause of Afghan culture in how we operate and relate to each other. Failing this, we ourselves risk becoming a major part of the problem. 